broad decriminalization of hard drugs. Alphonso Lingis's 'Love Junkies' is a moving dialogue featuring long-term prisoners and addicts Cheryl and Wayne, whose relationship is exemplary and extraordinary despite its physical restrictions (although I was surprised to see the editors' introduction carelessly refer to Wayne's 'full blown AIDS' (p. 12)). Finally, John Fitzgerald's examination of the 'scopic technologies' utilized by public health in its efforts to monitor drug users, and the elusiveness of 'hidden populations' such as dance party Ravers is a brilliant example of Foucauldian analysis. Its nuanced account of the 'circular sleight of hand between scientific visibility and invisibility' has implications well beyond the essay's particular focus (p. 357).

Overall, this is an innovative and rewarding collection, which reveals the sometimes surprising intimacies between addiction and art, literature and philosophy.

doi:10.1057/palgrave.fr. 9400347

Helen Keane

\title{
Nationalism and gender
}

Chizuko Ueno (translated by Beverley Yamamoto); Trans Pacific Press, Melbourne, 2004, 263p, ISBN 1-8768-4353-5, £19.99 (Pbk), ISBN 1-87684359-4, £48.00 ( Hbk)

As Ueno says in the Epilogue, this book is about 'History'. 'History', however, not in a sense of events that happened in the past, but as an actual construction of the past, which is a project in progress and at the same time extremely political.

The existence of 'Military Comfort Women' who were systematically raped by the Imperial Japanese Military during the Second World War became widely known about after these women started to testify to their ordeals in the 1990s. The issue has particularly attracted the attention of feminists, who regard the 'Military Comfort Women' system as one of the worst examples of sexual violence against women. In addition, it has stirred up the interests of those concerned with Japanese war responsibility and reparation affairs. This has resulted in the emergence of various historical and political debates and movements, two of which are most significant. One of the movements is that of feminist and leftist historians who endeavour to reflect and re-write history through these women's testimonies. The other is the revisionist movement which refutes the validity of these women's testimonies.

As the translator of the book Yamamoto suggests Ueno has been frustrated by the fact that the debates around this issue have often been confined to the positivist 
historical perspective. This is because such a perspective, which is often employed by feminists and the leftist historians, has proved to be ineffective in challenging the Japanese revisionist arguments on 'Comfort Women'. The first section of the book, 'Engendering the Nation', examines how the modernization of Japan and the Asian-Pacific War has been interpreted by intellectuals in Japan. It also highlights the way in which Japanese feminists, who explore women's history, are bound by the concepts and practices of the nation state. The second section, 'The Military Comfort Women Issue', looks at the various discursive paradigms (strategies) applied in 'Comfort Women' debates. Ueno underlines the strength and limitations of each strategy which include those employed by revisionists, leftists and feminists. The third part, 'The Politics of Memory', deals with Japanese revisionist arguments on 'Comfort Women', and analyses the way that leftist and feminist historians challenge them. In so doing, Ueno draws attention to the political process of history construction. The fourth section, 'Hiroshima from a Feminist Perspective: Between War Crimes and the Crime of War', is an addition particular to this new English edition (the original Japanese edition was published in 1998). It provides the conclusion to this book, where Ueno stresses the importance of feminists challenging 'legitimized' violence carried out in the name of the nation state.

Although each section can be read on its own, the central aim which runs through Nationalism and Gender is to emphasize the constructed nature, that is to say, the political and non-objective nature, of history. Ueno has achieved this mainly through the development of two themes: the nationalization process of women (in Japan) and Japanese feminists' reflection on this matter; and a historical quest for 'Truth'. Ueno argues that it is only in the 1980s that feminist historians in Japan started to look critically at how the category of women and gender was utilized (or actually constructed) in the process of modernization or the building of Japan's nation state. This also means that Japanese women, as an integral part of the structure of the nation state, bear some of the responsibility for the Asian-Pacific War, which was the fullest mobilization of the Japanese state. However, according to Ueno even this reflective school is not free from the influence of its national history. Most Japanese intellectuals see the wartime experience of Japan, the defeated country in Asia, as 'deviant', 'exceptional', or 'outside' of modernity, and place its causes in factors unique to Japan. Because of this, Japanese feminists have failed to contextualize the issue of 'Military Comfort Women' in a broader historical framework of (post)colonialism, and have also reinforced the sexual double standard which is prevalent in such historical perspectives.

Considering the quest for historical 'Truth', Ueno argues that the 'Comfort Women' supporters' belief that historical 'Truth' produced through their rigorous historical analysis can overpower the Japanese revisionist argument, is only the other side of the coin of revisionist logic. She maintains that they share with the 
revisionists the positivist historical perspective that attempts to uncover a final historical 'Truth'. Ueno, on the contrary, claims that there is no objective, single, historical 'Truth' but only different 'realities' for different people. For Ueno, testimonies are important not because they are useful in discovering a single authentic history, but because these various narratives of history themselves are the very process of constructing the past in the present.

Ueno's work has always been polemical and Nationalism and Gender is no exception. However, she has successfully raised crucial issues around 'Military Comfort Women' which many writers on this issue have failed to examine. And Ueno's analysis has a sharp critical edge. Nevertheless, she does not offer any alternative approach to history. If there exist multiple realities, as she claims, can we claim any realities as history? Where does judgement lie? Similarly, if feminism needs to transcend the state, how could this be achieved? It seems that she has left these questions for the reader to grapple with further.

Maki Kimura

doi:10.1057/palgrave.fr. 9400348

Rethinking Islam and liberal democracy: Islamist women in Turkish politics Yeşim Arat; State University of New York Press, Albany, 2005, $150 p$, ISBN 0-7914-6466-0 £12.00 (Pbk); ISBN 0-7914-6465-2 £34.50 (Hbk)

The book by Yeşim Arat sheds light in a very innovative way, on the much talked about uniqueness of the Turkish experience regarding female's emancipation and status. This is done by thoroughly detailing the mobilization and modes of participation of women in the Refah Party. The book clearly illustrates that when analysing women's participation in seemingly illiberal movements, to advocate their false consciousness is both an easy and simplistic way of looking into their participation. Instead, the research highlights a group of women who were apparently caught up in the webs of the private realm, but who were ready and willing to be politicized in the pursuit of their self-interests and in achieving selfrealization. One of the most interesting findings in Arat's research, is the way Refah women built up their constituency. Of particular interest is the author's emphasis on the significance of kinship and community ties in reaching over to other women and in politicizing them. Hence, the concept of 'apolitical politicization' can be a valuable theoretical tool in investigating women's political mobilization and passage from the private into the public sphere. Reading the book, the reviewer cannot help but think about the ongoing debate on the application of the concept of civil society to Middle Eastern societies which has been pervaded by arguments on whether such a concept, which implies 